\title{
Diabetes Mellitus, Leprosy: Intensive Education Protocol in Foot at Risk, Santa Marcelina Hospital, Amazon, Brazil
}

\author{
Orlando Leite ${ }^{1,2}$, Vanderneide Oliveria ${ }^{1}$, Augiceli Rodrigues ${ }^{1}$, Ticiana Albuquerque ${ }^{1}$, \\ Alexandre Carvalho², Larissa Gaspar², Alexandre Falqueti², Larissa Bianca Paiva Cunha de Sá ${ }^{2}$, \\ Alberto Krayyem Arbex ${ }^{2}$
}

${ }^{1}$ Division of Endocrinology Santa Marcelina Hospital, Porto Velho, Brazil

${ }^{2}$ Division of Endocrinology, IPEMED Medical School (IPEMED), São Paulo, Brazil

Email: olcpvh@hotmail.com

How to cite this paper: Leite, O., Oliveria, V., Rodrigues, A., Albuquerque, T., Carvalho, A., Gaspar, L., Falqueti, A., de Sá, L.B.P.C. and Arbex, A.K. (2017) Diabetes Mellitus, Leprosy: Intensive Education Protocol in Foot at Risk, Santa Marcelina Hospital, Amazon, Brazil. Open Journal of Endocrine and Metabolic Diseases, 7, 52-58. http://dx.doi.org/10.4236/ojemd.2017.71006

Received: November 24, 2016

Accepted: January 8, 2017

Published: January 11, 2017

Copyright $\odot 2017$ by authors and Scientific Research Publishing Inc. This work is licensed under the Creative Commons Attribution International License (CC BY 4.0).

http://creativecommons.org/licenses/by/4.0/

\begin{abstract}
Objective: To apply an intensive and multidisciplinary education protocol in order to decrease, improve, delay or cancel the beginning of neuropathy and the manifestation of lesions in diabetic patients. Methodology: This is a cross-sectional descriptive study carried out at the Diabetes Mellitus Outpatient Clinic and Ward of Santa Marcelina Hospital in Porto Velho. This research was based on cases of patients with Diabetes and Diabetics with Leprosy. The criteria used to include the patients were: being treated with insulin therapy, not to be amputated, being on high medication of the leprosy at the moment of the evaluation and to present nutritional risk classification by the screening. The population was divided into two groups of fifteen patients: eight diabetic patients, four male and four female. Seven diabetics associated with leprosy were 4 males and 3 females. The monofilament test (SemmesWeinstein $10 \mathrm{~g}$ ) was used as the classification basis. Results and Discussion: Group A, called the intensive care group, began diabetes education work with medical, nutritional and rehabilitation guidelines by a multidisciplinary team for an average period of 15 days in the ward and after discharged with biweekly monitoring. Group B, called conventional care, received the same guidelines in outpatient care and the monitoring followed the quarterly protocol. Both groups were evaluated and reassessed for a period of 180 days in the outpatient clinic. Group A consisted of 8 (100\%) patients, 4 (50\%) diabetics and 4 (50\%) diabetics and leprosy patients. Conclusion: Intensive education in diabetes showed an improvement in the sensitivity, healing and nutritional status of the patients, leading to an improvement in quality of life and disability level, reducing or delaying the beginning of neurological complications. The protocol intensive method demonstrated a $100 \%$ improvement in
\end{abstract}


patients in group A.

\section{Keywords}

Continuing Education, Foot at Risk, Healing

\section{Introduction}

The health care service in hospitalized patients of Santa Marcelina Hospital treats patients with wounds of different etiologies (Leprosy, cutaneous leishmaniasis, diabetes mellitus, arterial hypertension, peripheral venous insufficiency, pressure ulcer) [1]. Quality work has been developed to provide health solutions with excellence in the light of ethical, humanitarian and Christian values since 1975 [2]. According to the philosophy of SUS [Unified Health System] unifying and standardizing the care provided to these clients through the multidisciplinary team in the Prevention and Treatment of Wounds by acting and management in the challenging of prevention of wound risk and according to the Prevention Protocol and treatment of chronic ulcers and Diabetic foot [3]. Thus, the multi-professional team (physicians, nutritionists, nurses, psychologists, caseworker and physiotherapist) integrates this care as a result of developing and applying this protocol that formalizes this new characteristic that complements and integrates the customer service, always standardizing care [4] [5] (Table 1).

We know that the skin is the largest organ of the human being. Many times to keep the untouched skin and free from injury it is necessary to use different strategies. Therefore, this protocol provides several ways to prevent breakage of skin integrity avoiding the formation of a wound, without compromising its functions and not endangering the patient. The modern treatment is efficient and effective in achieving the entire scarring process of the lesion, with reduction of healing time, the cost of treatment and the risk of complications. Besides the best moist environment [6] [7] a satisfactory coverage can optimize the

Table 1. Intensive Education Protocol in foot at risk.

\begin{tabular}{|c|c|c|c|}
\hline \multicolumn{4}{|l|}{ 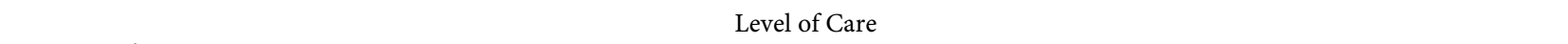 } \\
\hline & Evaluated and Reassessed & Group A 8 (100\%) & Group B 7 (100\%) \\
\hline & & $\begin{array}{l}6(75 \%) \text { Patients presented improvement in the } \\
\text { degree of sensitivity and progressed by screening } \\
\text { without nutritional risk. }\end{array}$ & $\begin{array}{l}1(14.2 \%) \text { patient had improvement. With } \\
\text { nutritional risk }\end{array}$ \\
\hline & & $2(25 \%)$ patients abandoned treatment. & $\begin{array}{l}2(28.57 \%) \text { patients is listed as stable. With } \\
\text { nutritional risk }\end{array}$ \\
\hline & & & $3(42.85 \%)$ patients with worsening status. \\
\hline & & & $1(14.2 \%)$ patient abandoned treatment. \\
\hline & From $15(100 \%)$ patic & nts of study, 1 (6.6\%) referring to Group A, progres & ssed to amputation \\
\hline
\end{tabular}


entire process of tissue remodeling. The characteristics of this best dressing have already been described by [5] and here we hereby try to maximize its use supporting the work developed by the professionals and the best use by the client. Howsoever, for a perfect treatment this service has standardized according to scientific researches and tests, behaviors and products, always finishing it in order to prevent infection, to reduce the healing time and to increase the patient's quality of life [8]. This protocol is subject to regular evaluations and necessary reformulations, according to the technological, scientific and political advances in health. In wound treatment, in addition to local factors, there are systemic factors that can affect the restore process of skin and tissues such as age, immobility, nutritional status, associated diseases and the use of continuous drugs, mainly immunosuppressive drugs. Among the local factors that affect the process, it is highlighted the anatomical location of the wound and the presence of infection and devitalized tissue [9] [10]. The wound treatment involves the evaluation of the patient's medical conditions, use of analgesics, care with the dressing and debridement of the infeasible tissue. Daily evaluation of the evolution of the wound is also necessary in order to continue or modify the previously established procedures [10].

\section{Leprosy and Care}

The strengthening of clinical research in Brazil implies the growth or consolidation of new knowledge. Brazil still has important endemics in its epidemiological context: leprosy, among others [11]. Leprosy disease is a compulsory notification, and in recent times the standards and criteria of control, treatment and surveillance system have been revised [12]. It is an infectious disease caused by $M$. leprae, an obligate intracellular bacterium with a prolonged incubation period, a broad spectrum of clinical signs of chronic evolution, mainly affecting the skin and peripheral nerves. Recent reviews of clinical aspects, immunology and chemotherapy in leprosy by national specialists are worth mentioning [13] [14]. The mixture of functional limitation, social prejudice and human suffering that accompanies leprosy explains why this disease is more feared than other diseases, including fatal illnesses. In several contexts, the negative social image of leprosy affects the evaluation and management of the damages, and the availability of effective measures for their prevention and treatment, with clear manifestation in the effectiveness of the developed actions in order to achieve their elimination [15]. A historical overview demonstrates that the hospital has turned its attention to aspects of curative medicine, which have made a very significant contribution in the progress of diagnosis and therapy [16]. The importance of the clinical staff's education, administration and patients of hospitals is highlighted as well as the general public as a means of making possible the integration of the assistance of leprosy patients in hospitals in short term. As a solution, the approach of the multidisciplinary team is proposed, emphasizing the value of leprosy being considered as a standard part of the general health problem and not as an isolated aspect. Due to these concerns, nutrition is an area of knowledge 
that participates in this context, being the professional that characterizes the present world very well, wherein the concern with the quality of life and prevention of diseases becomes increasingly [17].

\subsection{Nutritional Aspect for Treatment and Healing Monitoring.}

The healing process is directly related to the individual's nutritional status, since several nutrients participate in the formation of new tissues [18] [19]. Tissue repair and reconstruction require adequate amounts of energy, proteins, vitamins and minerals to feed the physiological mechanisms [20]. We often observe erroneous nutritional guidelines that end up hampering healing, since they have suspended important foods in this process. According to [21], an adequate nutrition is one of the most important aspects for the success of the healing process, because in the process of tissue regeneration, every phase requires nutritional elements for a good healing. Nutritional recovery may bring better results in healing time (Table 2).

\subsection{Institution Overview}

With a mission to provide an excellent health solution, in the light of ethical, humanitarian and Christian values whose core values are Faith, Hope and Love. Forty years later, each battle can be considered a great victory, since Santa Marcelina Hospital now has 100 beds, distributed in forty beds for the surgical area and sixty beds for the medical clinic area and other Specialty Outpatient Clinic; Radiology Clinic; Clinical Laboratory; Endoscopy; Ultrasound; Urology; Neurology; Physiotherapy and Rehabilitation; Orthopedics-Neurolysis, preventive

Table 2. Nutrients used in the Intensive Education [28].

\begin{tabular}{|c|c|c|c|}
\hline \multirow{2}{*}{ Group A } & Recommendation & Intensive Education & Food Source \\
\hline & \multicolumn{3}{|c|}{ Action } \\
\hline & Amino acids & $\begin{array}{l}\text { Inflammatory phase, homeostasis proliferative phase, } \\
\text { coagulation, activation of the local immune response }\end{array}$ & $\begin{array}{l}\text { Rice, beans, wheat germ, barley, milk asso- } \\
\text { ciated with oats, peas. }\end{array}$ \\
\hline & VITAMIN A-750 $\mu \mathrm{g}$ & $\begin{array}{l}\text { Proliferative phase, remodeling phase Regulates epidermal } \\
\text { development; } \\
\text { Increases the speed of collagen synthesis, deficiency: } \\
\text { susceptibility to infections }\end{array}$ & $\begin{array}{l}\text { Liver, egg yolk, green leaves like broccoli } \\
\text { and spinach, carrot and melon }\end{array}$ \\
\hline & VITAMIN B-3 mg & Remodeling phase Deficiency: skin dryness & Liver, dairy products, fish \\
\hline & VIT. C-100 to $300 \mathrm{mg}$ & $\begin{array}{l}\text { Proliferative phase Development of collagen, } \\
\text { improvement of tensile strength }\end{array}$ & $\begin{array}{l}\text { Citrus fruits, strawberry, pineapple, guava, } \\
\text { melon, kiwi and vegetables. }\end{array}$ \\
\hline & VIT. K-75 $\mu \mathrm{g}$ & $\begin{array}{l}\text { Inflammatory phase homeostasis, coagulation, } \\
\text { activation of the local immune response }\end{array}$ & $\begin{array}{l}\text { Liver, vegetable oils, dark green leafy veg- } \\
\text { etables such as cabbage and spinach }\end{array}$ \\
\hline & Ferro-15 mg & Proliferative phase production of collagen & Liver, red meat, poultry, fish, egg yolk \\
\hline & Zinc-12 - 15 mg & $\begin{array}{l}\text { Proliferative phase } \\
\text { Collagen formation, protein synthesis }\end{array}$ & $\begin{array}{l}\text { Red meat, fish, poultry, liver, milk and } \\
\text { dairy products, whole grains }\end{array}$ \\
\hline & Copper-10 - $12 \mathrm{mg}$ & $\begin{array}{l}\text { Inflammatory phase, remodeling phase Antioxidant, } \\
\text { elastin synthesis and collagen maturation }\end{array}$ & $\begin{array}{l}\text { Poultry, liver, oysters, nuts, dried fruit, } \\
\text { seafood, bread and meat }\end{array}$ \\
\hline & Protein-42 - $84 \mathrm{mg}$ & $\begin{array}{l}\text { Inflammatory phase, proliferative phase, remodeling phase. } \\
\text { Revascularization, synthesis and formation of collagen }\end{array}$ & Meat, fish, eggs, cheeses. \\
\hline
\end{tabular}


and corrective; Endocrinology; Auditory Center; Reference of Prosthetics; General and Vascular Surgery.

The Hospital has a clinical staff composed of thirty-two medical doctors, with the diverse specialties fields. They range from plastic surgeries, pediatric surgeries, and orthopedic surgeries, vascular surgeries, also clinical care and much more, including that it continues to be a status of reference point in the hospital treatment of Leprosy, Diabetes and wounds.

\section{Methodology}

It is a cross-sectional searching classified as descriptive because it is related to the investigation of a population defined in community, and will serve as the basis for the formulation of other researches, studies or hypotheses that can be searched. Regarding the approach, the research was a qualitative type because subjective order propositions have been admitted as well as interpretations of the authors and was still quantifiable. This research was conducted at Santa Marcelina Hospital, located at BR-364. KM-17, towards Cuiabá, outpatient clinics and Diabetes Mellitus ward. This study was based on cases of patients with Diabetes and Diabetics with Leprosy. The study demonstrates in a real way the care that must be taken in the treatment, in the approach and in the contact with the patient, demanding that the professional practice be conducted in an ethical way and above all things human values are respected [22] [23]. The researchers were always available with technical ability to perform the research, such as room for evaluation, anthropometry equipment, with computer, air conditioning, and internet available for research, free access in the male and female wings and laboratory where Biochemical tests were performed according to the unified health system [24] [25].

\subsection{Units}

Adult male and female patients diagnosed with infected and uninfected wounds confirmed by clinicians of Santa Marcelina Hospital and were hospitalized for at least 30 days. Being on insulin therapy, not having amputations, being on high medication of leprosy at the time of the evaluation and presenting a nutritional risk classification by screening. From March 2013 to August 2013, the population was divided into two groups of fifteen patients: eight diabetic patients, four male and four female. Seven diabetics associated with leprosy were 4 males and 3 females.

The monofilament test was used as the classification base (Semmes-Weinstein $10 \mathrm{~g})$.

The collection and processing of data will be defined according to statistical standards. The techniques that will be used are: Method/WHO for Sensitivity Assessment, Application of Nutritional Anamnesis, Social Aspects, Medical Diagnosis, Measurement Information Collection, Direct and Indirect Anthropometric Measurements, Laboratory Data, Systems Assessment, Regular Feeding or 24-Hour Reminder, Food Consumption Frequency and Nutritional Diagnosis. 
In order that the dietary intake did not influence the amount of nutrient found in the serum and plasma, a sample of $10 \mathrm{ml}$ of blood was collected at the time of admission, the individual was fasted, considered as the first collection and after 15 days the second obeying the same initial protocol. As for visceral protein indicators, plasma proteins and extra-vascular fluids represent approximately $3 \%$ of total body proteins whereas proteins of the visceral organs constitute approximately $10 \%$. When compared to other methods of evaluating the protein-calorie status, plasma protein measurements are fast, more accurate, cheaper and very useful for the nutrition professional, especially in the institutional health care setting.

\subsection{Equations}

Group A, called the intensive care group, began work on diabetes education with medical, nutritional and rehabilitation guidelines by a multidisciplinary team for an average period of 15 days in the ward and after medical discharge with biweekly monitoring. Group B, called conventional care, received the same guidelines in outpatient care and medical monitoring followed the quarterly protocol. Both groups were evaluated and reevaluated for a period of 180 days in the outpatient clinic [26] [27].

\section{Conclusion}

This research highlights, once again, the importance of integration among the specialties in order to benefit the patient improving their quality of life. Therefore, experimental models of multidisciplinary clinic outpatient of clinics should be encouraged in clinical practice to promote a more comprehensive care on different functional aspects. Intensive education in diabetes showed an improvement in the sensitivity, healing and nutritional status of the patients, leading to an improvement in quality of life and disability, reducing or delaying the inception of neurological complications. The intensive form of the protocol demonstrated a $100 \%$ improvement in patients in group A.

\section{References}

[1] Leão, L.S.C.S. (2003) Manual de Nutrição Clínica: Para atendimento ambulatorial do Adulto. Vozes,Petrópolis, RJ.

[2] Sabroza, P.C., Santos, E.M., Andrade, V. and Hartz, Z. (2000) Linhas de pesquisas operacionais na area de hanseníase no âmbito da vigilância em saúde-Uma proposta. Hansen Int., 25, 143-146.

[3] Slovic, P. (1987) Perception of Risk. Science, 236, 280-285. https://doi.org/10.1126/science.3563507

[4] Talhari, S. and Neves, R.G. (1997) Hanseníase. Instituto Superior de Estudos da Amazônia.

[5] Foss, N.T. (1999) Hanseníase: Aspect clínicos, imunológicos e terapêuticos. An Bras Dermatol, 74, 113-119.

[6] Zago, M.A. (2004) A pesquisa clínica no Brasil. Ciência e Saúde Coletiva, Rio de Janeiro. 
[7] Feliciano, K. and Kovacs, M.H. (1997) Opiniões sobre a doença entre membros da rede social de pacientes de hanseníase no Recife. Rev Panamericana de Salud Pública, Washinton.

[8] Noordeen, S.K. (1995) Elimination of Leprosy as Public Health Problem: Progress and Prospects. Bulletin of The World Health Organization, 73, 1-6.

[9] Rosen, G. (1994) Uma história de saúde pública. Unesp, Hucitec, Abrasco, São Paulo.

[10] Organização Mundial de Saúde (2000) Leprosy Global Situation. Weekly Epidemiological Record, 735, 225-232.

[11] Neto, F.T. (2003) Nutrição Clínica. Guanabara-Koogan, Rio de Janeiro.

[12] Ministério da Saúde (2000) Legislação sobre o controle da hanseníase no Brasil. Portaria 816 e $817 /$ GM de 26 de julho de.

[13] Gillis, T.P. and Krahenbuhl, J.L. (1998) Global Elimination of Leprosy. Reviews in Medical Microbiology, 9, 39-48. https://doi.org/10.1097/00013542-199801000-00005

[14] Harboe, M. (2000) Leprosy at a Turning Point. International Journal of Leprosy and other Mycobacterial Diseases, 68, 312-318.

[15] Minayo, M.C.S. (1991) Abordagem antropológica para avaliação de políticas sociais. Revista de Saúde Pública, 25, 233-238. https://doi.org/10.1590/S0034-89101991000300012

[16] Harboe, M., Hastings, R.C., et al. (1985) The Immunology of Leprosy. In: Hastings, R.C., et al., Leprosy, Churchill Livingstone, New York, 53-86.

[17] Leão, L.S.C.S. (2003) Manual de Nutrição Clínica: Para atendimento ambulatorial do Adulto. Vozes, Petrópolis.

[18] Neto, F.T. (2003) Nutrição Clínica. Guanabara-Koogan, Rio de Janeiro.

[19] Talhari, S. and Neves, R.G. (1997) Hanseníase. Instituto Superior de Estudos da Amazônia.

[20] Gracia, E.M. (2004) Manual de dietoterapia e avaliação nutricional. Editora Atheneu, São Paulo.

[21] Duarte, A.C. and Castellani, F.R. (2002) Semiologia Nutricional. Axcel, Rio de Janeiro.

[22] Smith, P.G. (1992) Revised Estimates of Global Leprosy Number. Leprosy Review, 62, 317-318. https://doi.org/10.5935/0305-7518.19920037

[23] Meima, A., Gupte, M.D., Van Oortmarssen, G.J. and Habbema, J.D.F. (1999) Simlep: A Simulation Model for Leprosy Transmission and Control. International Journal of Leprosy, 67, 215-236.

[24] Fine, P.E.M. (1992) Reflections on the Elimination of Leprosy. International Journal of Leprosy, 60, 71-80.

[25] Cho, S.N. and Brennan, P.J. (1999) New Biological Tools for Leprosy Surveillance. International Journal of Leprosy, 61, S59-S62.

[26] Visschedijk, J., Van, B.J., Eggens, H., Lever, P., et al. (2000) Review: Mycobacterium leprae-Millenium Resistant. Tropical Medicine \& International Health, 5, 380-399. https://doi.org/10.1046/j.1365-3156.2000.00572.x

[27] Guimarães, F.C. and Cruz, A.A. (1998) Eyelid Changes in Long Standing Leprosy. Ophthalmic Plastic and Reconstructive Surgery, 14, 239-243. https://doi.org/10.1097/00002341-199807000-00003

[28] Cree, I.A. and Smith, W.C. (1998) Leprosy Transmission and Mucosal Immunity: Towards Eradication. Leprosy Review, 69, 112-121. https://doi.org/10.5935/0305-7518.19980011 
Submit or recommend next manuscript to SCIRP and we will provide best service for you:

Accepting pre-submission inquiries through Email, Facebook, LinkedIn, Twitter, etc. A wide selection of journals (inclusive of 9 subjects, more than 200 journals)

Providing 24-hour high-quality service

User-friendly online submission system

Fair and swift peer-review system

Efficient typesetting and proofreading procedure

Display of the result of downloads and visits, as well as the number of cited articles Maximum dissemination of your research work

Submit your manuscript at: http://papersubmission.scirp.org/

Or contact ojemd@scirp.org 